\title{
THE MEXICAN COTTONTAIL (SYLVILAGUS CUNICULARIUS): A HISTORICAL PERSPECTIVE OF HUNTING AND GRAZING AND IMPLICATIONS FOR CONSERVATION PLANNING
}

\author{
KELSEY GILCREASE \\ Department of Chemistry and Applied Biological Sciences. South Dakota School of Mines and \\ Technology. 501 E. St Joseph Street. Rapid City, South Dakota 57702, USA. \\ $<$ Kelsey.gilcrease@sdsmt.edu $>$
}

Gilcrease, K. 2014. The Mexican Cottontail (Sylvilagus cunicularius): A historical perspective of hunting and grazing and implications for conservation planning. Acta Zoológica Mexicana (n.s.), 30(1): 32-40.

ABSTRACT. The Mexican cottontail (Sylvilagus cunicularius) is a widely hunted and locally important species in Mexico. The literature suggests that the Mexican cottontail population has declined and hunting and cattle grazing are speculated for a couple of reasons for population decline. Historical analyses can offer lessons to help aide in the conservation of this leporid species. This article examined the history of hunting and grazing in Mexico and assessed how these factors would have impinged on the Mexican cottontail. This historical analysis suggests that the Mexican cottontail was abundant at one time and was often eaten in prehistoric times. This paper provides examples of where practices, laws, and regulations led to deforestation and cattle pasture expansion such as The Law of Unproductive Land (1920) and Law on the Occupation and Alienation of Barren lands. These policies and practices would have facilitated continual use of agriculture and introduced feral fauna and grasses. This paper provides implications of hunting and grazing for conservation of the Mexican cottontail.

Keywords: Grazing, hunting, history, legislation, Mexican cottontail, Sylvilagus cunicularius.

Gilcrease, K. 2014. El conejo mexicano de monte (Sylvilagus cunicularius): Una perspectiva histórica de sucaza y del pastoreo, e implicaciones para planes de conservación. Acta Zoológica Mexicana (n.s.), 30(1): 32-40.

RESUMEN. El conejo mexicano (Sylvilagus cunicularius) es una especie ampliamente cazada y localmente importante en México. La literatura sugiere que la población de esta especie ha disminuido y la caza y el pastoreo de ganado se especuló por un par de razones para el declive de la población. Los análisis históricos pueden ayudar a ofrecer indicios para ayudar a la conservación de esta especie de lepórido. Este artículo examina la historia de la caza y el pastoreo en México y se evalúa cómo esos factores han incidido sobre el conejo mexicano. Este análisis histórico indica que el conejo mexicano fue abundante en un tiempo y, a menudo se come en los tiempos prehistóricos. Este documento ofrece ejemplos en los

Recibido: 29/08/2012; aceptado: 11/09/2013. 
que las prácticas, leyes y reglamentos dirigidos a la deforestación y la expansión de los pastizales para el ganado, tales como la ley de tierras improductivas (1920) y la Ley de la Ocupación y Enajenación de tierras estériles. Estas políticas y prácticas habrían facilitado el uso continuo de la agricultura e introdujo la fauna y las hierbas salvajes. Este documento proporciona implicaciones de la caza y el pastoreo para la conservación del conejo de rabo de algodón mexicano.

Palabras clave: el pastoreo, la caza, la historia, la legislación, conejo mexicano, Sylvilagus cunicularius.

\section{INTRODUCTION}

Although the Mexican cottontail was officially known as Sylvilagus cunicularius in 1909, literature reports that the rabbit has been in Mexico since approximately 5500 B.C. (Niederberger 1979) in people's diets, medicinal fortunes, and used for fur. The Mexican cottontail is an endemic leporid to central Mexico. Their range goes along the Transverse Volcanic Axis in arid lowlands, tropical deciduous, highland coniferous forest, and temperate highlands with grasses brush, and herbs, and pine-oak zone (Davis \& Russell 1954, Davis \& Lukens 1958, Cervantes et al. 1992) with abundant grassland and some forested areas (González 2007) and the rabbits are absent from overgrazed pasture outside of milpa fences (Leopold 1972). In addition, the Mexican cottontail is widely hunted (Davis \& Russell 1954, Cervantes et al. 1992, Uribe \& Arita 1998, González et al. 2007) and because of the large physical stature of the Mexican cottontail, hunters pursue the rabbit (Cervantes et al. 1992). Sylvilagus cunicularius is a widely distributed cottontail (Vázquez et al. 2007) however, once abundant, it now has a lower risk, near threatened status (Smith 2008). Furthermore, the rabbit was once abundant in Chamela, Jalisco until a few years ago (Cervantes et al. 1992). Population declines are thought to be due mainly to hunting and cattle grazing (Davis \& Russell 1954, Cervantes et al. 1992, Vazquez et al. 2007, González et al. 2007).

Currently, the literature focuses on the distribution of the rabbit (e.g. Davis \& Russell 1954, Mammals of Veracruz 1963, Diersing \& Wilson 1980, Fa et al. 1992, Cervantes et al. 1992, González et al. 2007) and the historical palaeontology remains of the Mexican cottontail rabbit (Dalquest 1961). However, a history of the Mexican cottontail's uses and laws/ordinances in relation to grazing/hunting in Mexico that apply to the cottontail has not been undertaken. Since the Mexican cottontail is an actively hunted and locally important species faced with many current population threats, such as hunting and grazing (Cervantes et al.1992, Vázquez et al. 2007), this necessitates a historical analysis of hunting and grazing. The objectives of this paper are to determine the uses of the Mexican cottontail and the laws/ordinances have been put in place that historically would have impacted the rabbit and implications toward the current rabbit population. Historical perspectives of hunting and grazing offers a way to understand how the rabbit was used and can help aide in the conservation of this leporid in central Mexico. 


\section{MATERIALS AND METHODS}

Keywords. Google book search key words: Mexican Cottontail, Sylvilagus cunicularius, "cunicularius hunting" date: 1900-1925, "conejos hunting" date: 1900-1925, "hunting" date: 1900-1925, "grazing" "Mexican cottontail" hunt*, "Mexican cottontail", "Mexico grazing", "Mexican grazing", "cattle grazing Morelos", "cattle grazing Jalisco". In addition, ISI web of knowledge was used under these key search terms: Mexican Cottontail, Sylvilagus cunicularius. Additional materials were selected that as new ideas and queries emerged, which led to additional resources (Holloway 1997).

Historical Research Method. Rowlinson (2005), Sreedharan (2007), and Connaway \& Powell (2010) contend that the historical research method is as follows: identify the problem/topic, collect data, and ensure that the data is valid and reliable, and finally, organize, analyze, and synthesize for conclusions. To ensure authentic and reliable research sources, Rowlinson (2005) suggests that each source must pass two evaluations consisting of external and internal criticism, where external criticism is the process of determining the validity of the source, and internal criticism is the process of determining the dependability or precision of the information (Rowlinson 2005). To pass the internal and external criticism tests, all materials used for this historical analysis were derived from peer-reviewed sources. Attention was paid to ensure the resource was referring to the Mexican cottontail.

Data and Thematic analysis. To assist with the creation of underlying principles from the historical information sources, the data and thematic analysis method was selected. With these methods, the researcher searches the data and lists categories with similar meaning (Holloway 1997). The process of data analysis is organizing the material, checking through the data, breaking down the material, identifying patterns of meanings, grouping categories, recognizing and describing patterns and themes, and examining data for meaning (Holloway1997).

\section{RESULTS}

History of hunting in Mexico. The use of the Mexican cottontail rabbit, population size, and seasonal hunting contribute to the history of hunting in Mexico.

Use of the rabbit. The Mexican cottontail was often found/eaten in Teotihuacan and its small villages (Manzanilla 1999). Some rabbits were bred in captivity and this activity might have been in response to meat shortages in 350-650 A.D. (Manzanilla 1996, Manzanilla 1999). Heath-Smith (2000) found a similar result in the Teotihuacan Valley where there were attempts to domesticate Sylvilagus cunicularius in 650900 A.D. as there were many faunal remains of cottontails (Heath-Smith 2000). In addition, rabbit feet were cut as a ritual in Teotihuacan and Durango, Mexico (Manzanilla 1996, Jacobo-Salcedo et al. 2011). Once the feet were cut off, rabbits were roasted with hot coals (Flannery 1967). 
Population size. It seems as though Zohapilco had a maximum availability of Mexican cottontails as food resources in 5500 B.C. and was available all year around (Niederberger 1979). In addition, Flannery (1967) predicted that the prehistoric (7000 B.C.-1500 A.D.) distribution of the Mexican cottontail was more prevalent in Ajalpan and El Riego on alluvial valley floors.

Seasonal hunting. While the method of hunting seemed to be that cottontails were snared and trapped on the valley floor (Flannery 1967), Flannery (1967) and Webster (1986) suggested that perhaps smaller fauna such as rabbits were trapped during wetter seasons because larger game was more difficult to find in wet seasons when vegetation was blossoming in 7000-3500 B.C.

History of grazing in Mexico. The type of grazing animals, land ordinances that took place, distance of grazing land from town limits, and size and shape of grazing land contribute to the history of cattle grazing in Mexico.

Type of animals. The domesticated animals that were introduced to Mexico in the $16^{\text {th }}$ century were chickens, ducks, sheep, pigs, cattle, goats, horses, and donkeys (Meyer \& Beezley 2000). In some areas in Mexico, the cattle multiplied and were turned wild (Chevalier 1966).

Land ordinances/tenure. Laws, tenure, and land ordinances impinge on how the land was managed, which may be important to the conservation of the Mexican cottontail. In 1532, all grazing land in Mexico was common property and one caveat included that town commons, private properties, and sheep lanes were to be guarded with fences (Chevalier 1966). Table 1 summarizes a variety of laws that were passed in regards to land use.

Distances of grazing land from villages. Since the cattle quickly multiplied, the Viceroy attempted to keep the land for cattle distant from villages and prevent cattle from coming into the Indian's maize and village limits (Chevalier 1966). As a result, a number of mechanisms were created. For example, in between the years 1550 and 1556, 20 Royal Decrees required the cattle land to be established remotely from villages and in fact, judges arrived to examine and remove the cattle land that were too close to villages (Chevalier 1966). In 1556, a buffer zone was established for native communities such that livestock could not come within a radius of 3,000 paces (Chevalier 1966). Next, in the land ordinance of May 26 and September 19, 1567, grazing land could not be within 1,000 varas (1 vara-about 33 inches) to native villages (Chevalier 1966). Lastly, around the end of the $16^{\text {th }}$ century, the Spanish government passed laws that from January 1-February 28, the consumption of harvest stubble as forage was constrained and cattle and horses needed to be away from well-populated areas (Meyer \& Beezley 2000).

Size and shape of land for cattle. In 1563, the measurements of the land for livestock were set to be 3,000 square paces and 2,000 square paces for cattle and sheep respectively (Chevalier 1966). The land was common land until 1602 and there was circular land sold to private parties for cattle (Chevalier 1966). 
Gilcrease: A historical perspective of the Mexican cottontail

Table 1. Summary of legislation in relation to agriculture use and cattle grazing.

\begin{tabular}{|c|c|c|}
\hline Legislation & Year & Implementation \\
\hline Policy of Congregaciones & 1542 & $\begin{array}{l}\text { People would need to cultivate the land for three } \\
\text { years or lose it (Assies 2008). }\end{array}$ \\
\hline $\begin{array}{l}\text { Law on the Occupation and } \\
\text { Alienation of Barren Lands }\end{array}$ & 1894 & $\begin{array}{l}\text { Identified lands without an owner and sold (Assies } \\
\text { 2008). }\end{array}$ \\
\hline Agrarian Reform Act & 1915 & $\begin{array}{l}\text { The nation would have power over privately held } \\
\text { land, but land could be reallocated to the public. For } \\
\text { example, villagers could petition the government } \\
\text { to seize private properties and create an ejido, but } \\
\text { to grant the land to the villagers, land needed to be } \\
\text { worked regularly (Merrill and Miró 1996). }\end{array}$ \\
\hline The Constitution of 1917 (Article 27) & 1917 & $\begin{array}{l}\text { Made communal landholding the major form of land } \\
\text { tenure in Mexico and could be transferred to private } \\
\text { property (Assies 2008). }\end{array}$ \\
\hline Law of Unproductive Land & 1920 & $\begin{array}{l}\text { Land used for other than agriculture could be } \\
\text { claimed (González-Monagut 1999). }\end{array}$ \\
\hline Agrarian Reform Law & 1943 & $\begin{array}{l}\text { Permitted producers with concessions for cattle } \\
\text { ranching to retain a small area that was to be used } \\
\text { for cattle raisingwhen the concession terminated } \\
\text { (González-Monagut 1999). }\end{array}$ \\
\hline
\end{tabular}

\section{DISCUSSION}

The historical literature on hunting and grazing in Mexico is scarce, especially for consecutive dates and timelines. Given the literature, the Mexican cottontail was available all year around (Niederberger 1979) and it was the most common animal during prehistoric times for food, and it seems as though the Mexican cottontail rabbit was very abundant.

Hunting. In order to help answer the question of what factors might have led to the decline of the Mexican cottontail population, the historical use of the rabbit, population size, seasonal hunting, and hunting laws must be considered.

Use of the rabbit and population size. The results suggest that the rabbit was used for many purposes, not just eating. This study also suggests that the rabbit was abundant. Currently, there is a question on how abundant the rabbit is in Mexico as the population trend is unknown on the IUCN Red List of Threatened Species (IUCN 2013).

Seasonal hunting. Since the Mexican cottontail breeds throughout the year, especially during warmer, wetter months, Vazquez et al. (2007) recommended that hunting the rabbit only occur from November to February. The current national hunting calendar, the Calendario Cinegético has hunting occur from September to March (SEMARNAT 2012). In addition, Vazquez et al. (2007) points out that legal hunting does 
not account for reproduction seasons or the age structure of Mexican cottontails.

Despite the claims for concerns for the cottontail population, Uribe \& Arita (1998) suggest that because the Mexican cottontail covers $40 \%$ of the country, the population size of the Mexican cottontail is not as much of a concern. However, Uribe \& Arita (1998) suggested that there is a need to reconsider elements for management and certain species because the distribution of species is unknown.

An alternative viewpoint was presented by Leopold (1972) which suggested that rabbit hunting should be encouraged because the cottontail populations can reach such high abundances that they can with stand hunting pressure. This view point may be applicable when populations are healthy, but when the population size is unknown, further research is needed to ensure viable populations of the Mexican cottontail. Furthermore, intense hunting of the cottontail is discouraged (Davis \& Russell 1954, Cervantes et al. 1992).

Implications of hunting would be to alter the national hunting calendar accordingly during times when the rabbit is not breeding as often and consider the age structure of the population, following the recommendations of Vázquez et al. (2007). There is a need for further research on the distribution of rabbits.

Grazing. In order to help answer the question of what factors might have led to the decline of the Mexican cottontail population, the land ordinances and tenure, distances of grazing lands from villages, size and shape of land for cattle must be considered. It could be possible that more current practices, laws, and tends that have contributed to the population decline of the Mexican cottontail.

Land ordinances and tenure. One of the objectives of this paper was to identify laws that would be relevant to the Mexican cottontail. Leopold (1972) contends that excessive grazing to bare ground will deplete the rabbit population and over grazing in Mexico has occurred (Chapman \& Ceballos 1990, Kaus 1993, Galindo-Leal et al. 1993, González et al. 2007). There were laws and subsidies that contributed to further grazing activity or continual use of land (e.g. Forestry Law and Regulations 1992, Communal Land Tenure 1993 Law of Congregaciones, The Law of Unproductive Land in 1920, The Law on the Occupation and Alienation of Barren Lands and in 1938, and The Agrarian Code of 1943, and PROCAMPO (Ochoa-Gaona et al. 2000, Klepeis \& Vance 2003). These examples demonstrate the promotion of continual cattle grazing or land use, rather than opting to find grazing management alternatives that optimize cattle production and consider native pasture growth. For example, Holechek et al. (2003) contends that grazing at approximately $35 \%$ use of grasses increased forage productivity than moderate grazing (about $45 \%$ use of grasses).

The more recent population decline of the Mexican cottontail may be due to creeping normalcy. For example, Zizumbo-Villarreal \& Colunga-García Marín (2010) pointed out that the use of fire, increase in weeds, decreasing amount of forest, and distribution of new plants would have resulted from when people arrived in central 
Mexico. In addition González-Montagut (1999) suggested that slash and burn agriculture and the introduction of Zebu cattle in 1920's introduced new diseases such as foot and mouth disease. Finally, introduced grasses, feral fauna, pest infestations, and additional nutrients for sustaining crop yields (González-Montagut 1999, Trejo and Dirzo 2000, Klepias \& Vance 2003 \& González et al. 2007) would have decreased the cover for the cottontail. This necessitates the cottontail to adapt to new vegetation types and exotic species. These examples may have contributed to the creeping normalcy.

Distances of grazing land from villages. Successful cottontail conservation efforts on grazing depend on the level of grazing that occurs. Leopold (1972) found that when it comes to grazing, too much livestock grazing that result in bare ground will repel the rabbit population. Therefore, the closer that the cattle would have come to the villages would not be as favorable to the cottontail, as the cattle would reduce the cover for the cottontail (Szuter \& Bayham 1989). Accordingly, the buffer zones $(1,000$ varas $)$ around the villages would have benefited the rabbit because the rabbit requires cover.

Size and shape of land for cattle. Currently, there are no studies that examine edge effect on the Mexican cottontail. A circular patch shape has less edge and as a result, the circular land for cattle that was sold to private individuals in 1602 would have provided less edge effect in the landscape.

Implications for conservation in regards to grazing would be to increase the amount of pasture grass where the cottontail's preferred habitat is located (González et al. 2007). Precaution and careful planning must be observed such that the cottontail's preferred grasses includes Mexican broomroot, Peruvian feathergrass, and fescue grasses (Cervantes et al. 1992) could be planted. For the Mexican cottontail in Morelos, Trejo \& Dirzo (2000) pointed out that slopes higher than 12 degrees were not as heavily grazed. Management implications could consider that re-growth of pasture may occur faster on the higher slopes (where less grazing damage occurred) in areas where cottontails are below threshold. However, if the population is stable in some areas during certain seasons such as La Malinche (González et al. 2007, Vázquez et al. 2007), management efforts may restore the old pasture lands 12 degrees or less. This way, damaged pasture will have some time to be restored. While this study focused on hunting and grazing, further research could investigate the impacts of fire, introduced grasses, feral fauna, and vegetation changes and implications for the Mexican cottontail. Additional research could also focus on the impacts of deforestation and the amount of preferred grasses that the cottontail feeds on.

ACKNOWLEDGements. The author was very thankful for the comments provided by the three anonymous reviewers of this manuscript. 


\section{LITERATURE CITED}

Assies, W. 2008. Land Tenure and Tenure Regimes in Mexico: An Overview. Journal of Agrarian Change, 8: 33-63.

Cervantes, F. A., Lorenzo, C., Vargas, J. \& Holmes, T. 1992. Sylvilagus cunicularius. Mammalian Species, 412: 1-4.

Chapman, J. A. \& Ceballos, G. 1990. The cottontails, pp. 95-110. In: J. Chapman \& J. Flux (Eds.). Rabbits, Hares, and Pikas Status Survey and Conservation Action Plan. IUCN/SSC Lagomorph Specialist Group, Gland Switzerland.

Chevalier, F. 1966. Land and Society in Colonial Mexico. University of California Press, USA.

Cohen, L., Manion, L. \& K. Morrison. 2000. Research Methods in Education. Routledge, New York, USA.

Connaway, L. S. \& Powell, R. R. 2010. Basic Research Methods for Librarians. Libraries Unlimited, Santa Barbara, USA.

Dalquest, W. W. 1961. Sylvilagus cunicularius in the Pleistocene of Mexico. Journal of Mammalogy, 42: 408-409.

Davis, W. B. \& Lukens, Jr., P. W. 1958. Mammals of the Mexican State of Guerro, Exclusive of Chiroptera and Rodentia. Journal of Mammalogy, 39: 347-367.

Davis, W. B. \& Russell, R. J. 1954. Mammals of the Mexican State of Morelos. Journal of Mamma$\log y, 35: 63-80$.

Diersing, V. E. \& Wilson, D. E. 1980. Distribution and Systematics of the Rabbits (Sylvilagus) of West Central Mexico. Smithsonian Contributions to Zoology, 297: 1-34.

Fa, J. E., Romero, F. J. \& Lopez-Paniagua, J. 1992. Habitat use by parapatric rabbits in a Mexican high-altitude grassland system. Journal of Applied Ecology, 29: 357-370.

Flannery, K. V. 1967. Vertebrate Fauna and Hunting Patterns, pp. 132-177. In: D. S. Byers (Ed.). The Prehistory of the Tehuacan Valley Environment and Subsistence. University of Texas Press, Austin, USA.

Galindo-Leal, C., Angeles Morales, A. \& Weber, M. 1993. Distribution and Abundance of Coues deer and cattle in the Michilia Biosphere Reserve, Mexico. The Southwestern Naturalist, 38: 127-135.

González, J., Lara, C. Vázquez, J. \& Martínez-Gómez, M. 2007. Demography, density, and survival of an endemic and near threatened cottontail Sylvilagus cunicularius in central Mexico. Acta Theriologica, 52: 299-305.

González-Montagut, R. 1999. Factors that Contributed to the Expansion of Cattle Ranching in Veracruz, Mexico. Mexican Studies, 15: 101-130.

Heath-Smith, C. 2000. Analysis of Faunal Material Recovered from Xochicalco, pp. 184-192. In: K. Hirth (Ed.). Archaeogical Research at Xochicalco. University of Utah Press, Salt Lake City, USA.

Holechek, J., Galt, D., Joseph, J., Navarro, J., Kumalo, G., Molinar, F. \& Thomas, M. 2003. Moderate and light cattle grazing effects on Chihuahuan Desert Rangelands. Journal of Range Management, 56: 133-139.

Holloway, I. 1997. Basic Concepts for Qualitative Research. Blackwell Science, Oxford, UK.

IUCN. 2013. IUCN Red List of Threatened Species v. 2013.1. http://www.iucnredlist.org [accessed 15 July 2013].

Jacobo-Salcedo, M., Alonso-Castro, A. J. \& Zarate-Martinez, A. 2011. Folk medicinal use of fauna in Mapimi Durango, Mexico. Journal of Ethnopharmacology, 133: 902-906.

Kaus, A. 1993. Environmental Perceptions and Social Relations in the Mapimí Biosphere Reserve. Conservation Biology, 7: 398-406.

Klepias, P. \& Vance, C. 2003. Neoliberal Policy and Deforestation in Southeastern Mexico: An Assessment of the PROCAMPO program. Economic Geography, 79: 221-240. 
Leopold, A. S. 1972. Wildlife of Mexico: The Game Birds and Mammals. The University of California Press, Berkeley, USA.

Manzanilla, L. 1996. Corporate groups and domestic activities at Teotihuacan. Latin American Antiquity, 7: 228-246.

Manzanilla, L. 1999. The Emergence of Complex Urban Societies in Central Mexico: The Case of the Teotihuacan, pp. 90-126. In: G. Politis \& B. Alberti (Eds.). Archaeology in Latin America. Routledge, New York, USA.

Merrill, T. L. \& Miró, R. 1996. Mexico: A country study. Library of Congress, Washington, USA.

Meyer, M. C. \& Beezley, W. H. 2000. The Oxford History of Mexico. Oxford University Press, New York, USA.

Niederberger, C. 1979. Early sedentary economy in the Basin of Mexico. Science, New Series, 203: 131-142.

Ochoa-Gaona, S. \& M. González-Espinosa. 2000. Land use and deforestation in the highlands of Chiapas, Mexico. Applied Geography, 20: 17-42.

Rowlinson, M. 2005. Historical Research Methods, pp. 295-314. In: R. Swanson \& E. Holton III (Eds.). Research in Organizations. Barrett-Kohler, San Francisco, USA.

SEMARNAT. 2012. Calendario de Epocas Habiles 2011-2012, For Entidad Federativa. http://www. semarnat.gob.mx/temas/gestionambiental/vidasilvestre/Documents/Epoca_Habil_2011_2012/Sinaloa.pdf [accessed 04/10/2012].

Smith, A. T. 2008. Conservation of Endangered Lagomorphs, pp. 297-316. In: P.C. Alves, N. Ferrand, \& K. Hackländer (Eds.). Lagomorph Biology: Evolution, Ecology, and Conservation. Springer, Berlin, GER.

Sreedharan, E. 2007. A manual of historical research methodology. Centre for South Indian Studies, Kudappanakunnu, India.

Szuter, C. \& Bayham, F. 1989. Sedentism and prehistoric animal procurement among desert horticulturalists of the North American Southwest, pp. 80-95. In: S. Kent (Ed.). Farmers as Hunters: The Implications of Sedentism. Cambridge University Press, Cambridge, USA.

Trejo, I. \& Dirzo, R. 2000. Deforestation of seasonally dry tropical forest: a national and local analysis in Mexico. Biological Conservation, 94: 133-142.

Uribe, J. \& Arita, H. T. 1998. Distribución, diversidad y conservación de los mamíferos de importancia cinegetica en México. Acta Zoologica Mexicana (n. s.), no. 075: 47-71.

Vázquez, J., Martínez Chacón, A. J., Hudson, R., Rodríguez-Martínez, L. \& Martínez-Gómez, M. 2007. Seasonal reproduction in Mexican cottontail rabbits Sylvilagus cunicularius in La Malinche National Park, central Mexico. Acta Theriologica, 52: 361-369.

Webster, G. S. 1986. Optimization Theory and Pre-Columbian Hunting in the Tehuacan Valley. Human Ecology, 14: 415-435.

Zizumbo-Villarreal, D. \& Colunga-García Marín, P. 2010. Origin of agriculture and plant domestication in West Mesoamerica. Genetic Resources and Crop Evolution, 57: 813-825. 